\title{
Asynchronism in leaf and wood production in tropical forests: a study combining satellite and ground-based measurements
}

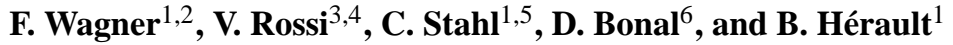 \\ ${ }^{1}$ CIRAD, UMR “Ecologie des Forêts de Guyane”, Kourou, French Guiana \\ ${ }^{2}$ National Institute for Space Research (INPE), São José dos Campos, SP 12227-010, Brazil \\ ${ }^{3}$ Cirad, UR105 "Biens et services des écosystèmes forestiers tropicaux", Montpellier, France \\ ${ }^{4}$ Université de Yaoundé, UMI209 “Modélisation Mathématique et Informatique de Systèmes Complexes”, BP337, Yaoundé, \\ Cameroun \\ ${ }^{5}$ CIRAD, UMR “Systèmes d'Elevage en Milieux Méditerranéens et Tropicaux”, Kourou, French Guiana \\ ${ }^{6}$ INRA, UMR EEF 1137, 54280 Champenoux, France
}

Correspondence to: F. Wagner (wagner.h.fabien@gmail.com)

Received: 15 April 2013 - Published in Biogeosciences Discuss.: 16 May 2013

Revised: 30 September 2013 - Accepted: 18 October 2013 - Published: 14 November 2013

\begin{abstract}
The fixation of carbon in tropical forests mainly occurs through the production of wood and leaves, both being the principal components of net primary production. Currently field and satellite observations are independently used to describe the forest carbon cycle, but the link between satellite-derived forest phenology and field-derived forest productivity remains opaque. We used a unique combination of a MODIS enhanced vegetation index (EVI) dataset, a wood production model based on climate data and direct litterfall observations at an intra-annual timescale in order to question the synchronism of leaf and wood production in tropical forests. Even though leaf and wood biomass fluxes had the same range (respectively $2.4 \pm 1.4$ and $2.2 \pm 0.4 \mathrm{MgC} \mathrm{ha}^{-1} \mathrm{yr}^{-1}$ ), they occurred separately in time. EVI increased with leaf renewal at the beginning of the dry season, when solar irradiance was at its maximum. At this time, wood production stopped. At the onset of the rainy season, when new leaves were fully mature and water available again, wood production quickly increased to reach its maximum in less than a month, reflecting a change in carbon allocation from short-lived pools (leaves) to long-lived pools (wood). The time lag between peaks of EVI and wood production (109 days) revealed a substantial decoupling between the leaf renewal assumed to be driven by irradiance and the water-driven wood production. Our work is a first attempt to link EVI data, wood production and leaf phenology at a seasonal timescale in a tropical evergreen rainforest and pave
\end{abstract}

the way to develop more sophisticated global carbon cycle models in tropical forests.

\section{Introduction}

Tropical forests have a primordial role in the terrestrial carbon (C) cycle. First, $55 \%$ of the total forest $\mathrm{C}$ stocks are stored in live biomass, deadwood, litter and soil of tropical areas ( $471 \pm 93 \mathrm{PgC}$ ). Second, carbon sequestration in tropical intact forests represents about half $\left(1.19 \pm 0.41 \mathrm{PgC} \mathrm{yr}^{-1}\right.$ for the period 1990-2007; Pan et al., 2011; Baccini et al., 2012) of the total sink in global established forest. Most carbohydrates are produced by photosynthesis in leaves and redistributed to plant tissues or lost during chemical processes such as respiration (Kozlowski, 1992). Accumulation of carbohydrates in woody tissues during secondary growth constitutes the main component of carbon sequestration in trees. Tree growth occurs in two ways: primary growth, which corresponds to the length extension of shoots from the apical meristems, where the leaves grow, and to root development, and secondary growth, which corresponds to all the biological mechanisms behind cambial activity and stem growth in thickness (Kozlowski, 1992). In this paper, we will use seasonal tree diameter growth as a proxy of seasonal variations in wood production and leaf phenology to assess leaf production, extension and fall. Wood and leaf production are the 
main components of net primary production and constitute the long-lived pool (wood) and the short-lived pool (leaves) of carbon in the trees (Malhi and Grace, 2000; Malhi et al., 2011). We will study the seasonality and the temporal decoupling between leaf and wood production.

Seasonality of leaf phenology in tropical rainforests has been observed either from (i) field measurements of litterfall and leaf production (Chave et al., 2010; Zalamea and Gonzalez, 2008; Bonal et al., 2008; Sabatier and Puig, 1986) or (ii) satellite data (Huete et al., 2006; Asner et al., 2000, 2004; Caldararu et al., 2012; Pennec et al., 2011). The latter studies characterize leaf phenology through variations in different vegetation indices, i.e. leaf area index (LAI), normalized difference vegetation index (NDVI) or enhanced vegetation index (EVI) (Justice et al., 1998). These indices are computed based on measurements of surface reflectance by sensors on board satellites. The drivers of leaf phenology in tropical rainforests are still studied, but recent results suggest that irradiance is the main driver throughout Amazonia (Bradley et al., 2011). Flushes of new leaves with increased photosynthetic capacity have been observed in the dry season and appeared correlated with seasonal peaks in solar irradiance (Huete et al., 2006; Myneni et al., 2007; Brando et al., 2010; Saleska et al., 2003; Caldararu et al., 2012; Wright and Vanschaik, 1994; De Weirdt et al., 2012).

Seasonal rhythms of secondary growth, i.e. wood production, in tropical forests have been highlighted in most longterm permanent plots (Nepstad et al., 2002; Stahl et al., 2010; Wagner et al., 2012), even under very stable climate conditions (O'Brien et al., 2008; Clark et al., 2010). This seasonality is obviously linked to the intra-annual variation of cambial activity that has been reported in various environments, from dry (Worbes, 1999; Enquist and Leffler, 2001; Lisi et al., 2008) to flooded forests (Schongart et al., 2002), but also in more mesic environmental conditions (Fichtler et al., 2003; Clark et al., 2010). Current studies performed in tropical rainforests have highlighted three major climate drivers of secondary growth, rainfall, solar irradiance and air temperature: (i) rain or lack of rain is often implicitly viewed as the main driver of rainforest dynamics (Phillips et al., 2009), as annual net primary production (NPP) generally positively correlates with the annual amount of precipitation (Tian et al., 1998). Recently, Wagner et al. (2012) showed that rainfall seasonality plays a key role in the tropical forests' response to climate variability. (ii) Irradiance is directly linked to plant photosynthetic capacity, in turn driving carbon uptake and plant growth (Graham et al., 2003). (iii) Recent studies suggest that tropical tree mortality may increase significantly with increasing night-time temperature, while seasonal tree growth appears surprisingly very sensitive to $1-2{ }^{\circ} \mathrm{C}$ variations in mean annual night-time temperature (Clark et al., 2010). Some works suggest that reductions in photosynthetic rate may occur at temperatures above $30^{\circ} \mathrm{C}$ and are driven by reductions in stomatal conductance in response to higher leaf-to-air vapour pressure deficits
(Lloyd and Farquhar, 2008) or by a direct down regulation of biochemical processes during $\mathrm{CO}_{2}$ fixation (Doughty et al., 2008; Doughty, 2011).

Field measurements of productivity, reported as biomass gain or growth in diameter at breast height (DBH), showed an increase in the wet season (Wagner et al., 2012; Grogan and Schulze, 2012; Nepstad et al., 2002; Clark et al., 2010); satellite measurements of productivity, reported in terms of increasing canopy photosynthetic capacity, were correlated with leaf production and peaked in the dry season (Huete et al., 2006; Brando et al., 2010; Anderson, 2012). In this study, we use a unique combination of three independent data sets to resolve this apparent absence of synchronism in leaf and wood production in tropical forests. First, $3 \mathrm{yr}$ of intensive field measurements of diameter growth of 256 tropical trees was used to calibrate a wood production model. Next, litter production was surveyed every 25 days in the same period in the same forest area. Finally, leaf production was estimated using EVI data from the Moderate Resolution Imaging Spectroradiometer (MODIS) sensor of the satellite Terra. We hypothesized that this asynchronism of biomass production in tropical forests reflects seasonal variations of wood and leaf production. We addressed two specific questions: (i) whether field and satellite data converge in describing the biological functioning of tropical forests, and (ii) how these two sources of information explained seasonal variations in tropical forest productivity. To our knowledge, this study is the first attempt to link leaf phenology, wood production and EVI data at a seasonal timescale.

\section{Methods}

\subsection{Field data}

Seasonal changes in trunk circumference were monitored in 256 trees from 74 species using self-manufactured steel dendrometer bands, distributed in 3 inventory plots (Stahl et al., 2010; Wagner et al., 2012) in Paracou, French Guiana $\left(5^{\circ} 18^{\prime} \mathrm{N}, 52^{\circ} 23^{\prime} \mathrm{W}\right)$, a lowland tropical rainforest (GourletFleury et al., 2004). These 0.5 ha inventory plots are distributed on a typical topographic gradient for this forest type (Sabatier et al., 1997). Changes in trunk circumference were censused every ca. 40 days from 2007 to 2010 (mean $=39$ and $s d=19.8$ in days). Trunk bark thickness and trunk bark density were measured respectively on 255 and 222 of the 256 studied trees (methods described in Stahl et al., 2010). In the same 3 inventory plots, 12 litter traps $\left(0.67 \mathrm{~m} \times 0.67 \mathrm{~m}=0.45 \mathrm{~m}^{2}\right)$ were placed $1.5 \mathrm{~m}$ above the ground at each corner of each plot. Trap contents were collected every 25 days on the same day and oven-dried at $60^{\circ} \mathrm{C}$ for 3 days until a constant weight before being weighed to the nearest $0.1 \mathrm{~g}$ (Bonal et al., 2008). Mean leaf area index (LAI) and standard deviation were estimated from measurements made with an Li-2000 (Licor, Lincoln, NE, USA) at between 
37 and 49 randomly selected locations in the same 3 inventory plots in March 2005, November 2005, November 2008, September 2010, March 2011, September 2011 and March 2012 (Bonal et al., 2008; Rowland et al., 2013). To highlight the temporal change in LAI, in 2011 and 2012, measurements were performed in March, in the middle of the wet season, and in September in the dry season, when a peak of litterfall had previously been observed (Bonal et al., 2008).

\subsection{Satellite data}

We used enhanced vegetation index (EVI) satellite data from the Moderate Resolution Imaging Spectroradiometer (MODIS) sensor on board the satellite Terra (EOS AM, NASA) (Justice et al., 1998). Vegetation indices are optical measures of vegetation canopy greenness, a composite property of canopy structure, leaf area and canopy chlorophyll content (Myneni et al., 1995). EVI is an index of canopy photosynthetic capacity (Huete et al., 2006). We obtained EVI from the Global MOD13Q1 data sets provided every 16 days at $250 \mathrm{~m}$ spatial resolution. The EVI maintains sensitivity even for high-LAI canopies by relying on near-infrared canopy reflectance, which is less prone to saturation with moderate resolution pixels (Gao et al., 2000; Huete et al., 2002, 2006). We used all 16-day composite EVI data from 4 January 2007 to 2 February 2011. For the MOD13Q1 data sets, the bias of EVI due to the sensor view angle is corrected with the constrained view angle-maximum value composite (CVA-MVC) algorithm (Solano et al., 2010). Leaves were considered fully mature when EVI reached its highest value because it is assumed to represent the highest canopy photosynthetic capacity. In addition, we used a typology of French Guiana forest (Gond et al., 2011) to link the MODIS pixels to a forest type and to describe the seasonal variations of EVI in each forest type. This typology is defined with data from the VEGETATION sensor on board the SPOT-4 satellite (1 km spatial resolution). For a map of the forest typology, see Fig. 1 in Gond et al. (2011).

\subsection{Climate data}

In order to link tree growth with a climate dataset that can be extrapolated to all the French Guianan forest types, we needed to calibrate a tree growth model with the global climate data set available at this regional scale. We used the CRU-TS3.1 and CRU-TS3.10.01 monthly climate data sets for the period 2007-2010 of the Climate Research Unit (CRU) at the University of East Anglia (Mitchell and Jones, 2005). These data sets are calculated on high-resolution grids $\left(0.5^{\circ} \times 0.5^{\circ}\right)$ with data from more than 4000 weather stations distributed around the world (4 in French Guiana). Here we used cloud cover (cld), precipitation (pre), daily mean, minimal and maximal temperatures (respectively tmp, tmn and tmx), vapour pressure (vap) and potential evapotranspiration (pet). For the calculation of potential evapotranspira-

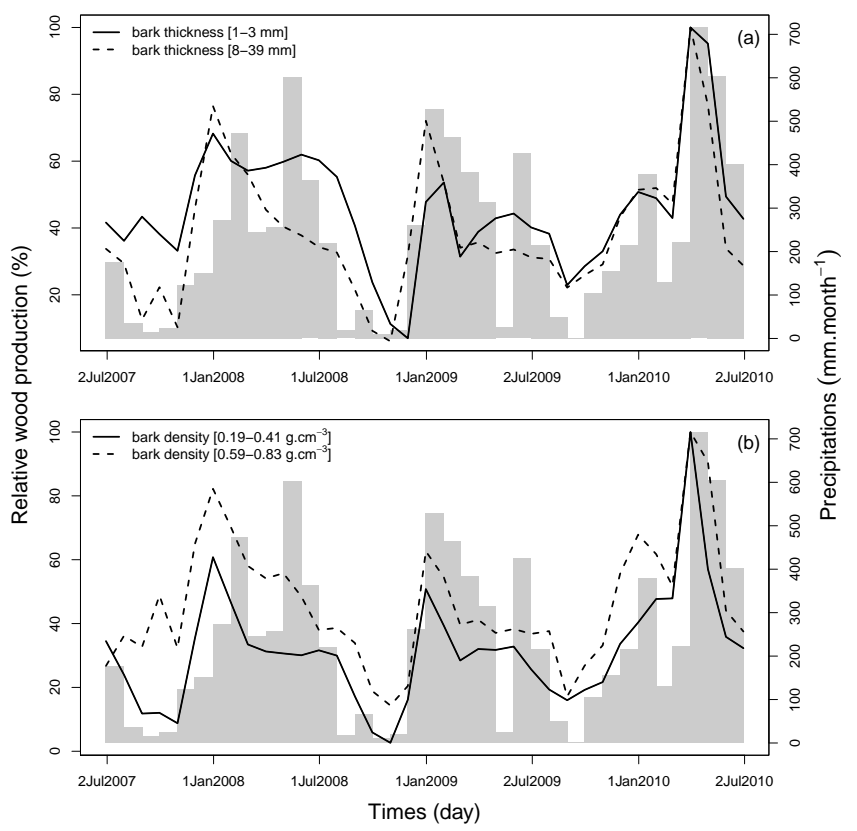

Fig. 1. (a) Monthly variation of wood production (percentage of maximum value) for the 71 trees in the first quantile of bark thickness (1-3 mm, low thickness, solid line) and the 67 trees in the last quantile of bark thickness (8-39 mm, high thickness, dashed line). (b) Monthly variation of wood production (percentage of maximum value) for the 58 trees in the first quantile of bark density (0.19$0.41 \mathrm{~g} \mathrm{~cm}^{-3}$, low density, solid line) and the 58 trees in the last quantile of bark density $\left(0.59-0.83 \mathrm{~g} \mathrm{~cm}^{-3}\right.$, high density, dashed line). Monthly sums of precipitations are represented with grey bars.

tion (pet), the method used is the Food and Agricultural Organization's (FAO) grass reference evapotranspiration equation (Ekstrom et al., 2007; Allen et al., 1994). It is a variant of the Penman-Monteith method using the gridded tmp, tmn, tmx, vap and cld. These data were estimated using linear approximation for the grid and the time of the MODIS image. Additionally, for the graphical representation, we used global radiation, mean temperature and relative extractable water (REW) measured or computed at Paracou (details of the sensors and computation of REW in Wagner et al., 2012 and Bonal et al., 2008). REW is a daily value between 0 and 1 : when REW $=1$, the amount of extractable water by the tree is at its maximum, and when REW $=0$, no water is available for trees. Mean monthly temperature of CRU data has a coefficient of correlation of 0.962 with mean monthly temperature measured in Paracou.

\subsection{Data analysis}

\subsubsection{Wood production versus stem hydration}

Changes in tree circumference are commonly used to characterize seasonal or annual variations in secondary growth. However, accelerated changes in circumference increments 
during the onset of the wet season can be caused by bark swelling as it becomes hydrated (Stahl et al., 2010). Similarly, bark shrinking during dry periods can mask any secondary growth and even lead to negative growth increments (Stahl et al., 2010). To disentangle the effect of climate seasonality vs. bark hydration on secondary growth and wood production, we compared the monthly biomass increments (see Eq. 3 for the computation of biomass from tree diameter) of two groups of trees corresponding to the first and the last quantile of trunk bark thickness and to the first and the last quantile of trunk bark density. Both groups showed synchronous and highly correlated variations (Pearson correlation coefficient of 0.80 for bark thickness and 0.87 for bark density) in biomass increment (Fig. 1), suggesting that secondary growth is driven by cambial activity.

\subsubsection{Modelling wood production}

We converted measured changes in circumference into wood production using the model of Molto et al. (2013). This model uses the diameter at breast height of the tree $i$ at the time $t\left(\mathrm{DBH}_{i, t}\right)$ to estimate the current height in metres $\left(H_{i, t}\right)$, Eq. (1):

$\log \left(H_{i, t}\right)=\log \left(\beta_{1} \times\left(\mathrm{DBH}_{i, t} /\left(\beta_{2}+\mathrm{DBH}_{i, t}\right)\right)\right)$,

where $\mathrm{DBH}_{i, t}$ is in $\mathrm{cm}, \beta_{1}=40.3$ and $\beta_{2}=9.43$. Then the wood production $\left(\mathrm{AGB}_{i, t}\right)$ was computed using the estimated height $\left(\hat{H}_{i, t}\right)$, the diameter $\left(\mathrm{DBH}_{i, t}\right)$ and the wood specific gravity of the tree ( $\mathrm{WSG}_{i}$ ), Eq. (3):

$$
\begin{aligned}
\log \left(\mathrm{AGB}_{i, t}\right) & =\beta_{3}+\beta_{4} \log \left(\mathrm{DBH}_{i, t}\right)+\beta_{5} \log \left(\hat{H}_{i, t}\right) \\
& +\beta_{6} \log \left(\mathrm{WSG}_{i}\right),
\end{aligned}
$$

where $\mathrm{DBH}_{i, t}$ is in $\mathrm{cm}, \hat{H}_{i, t}$ is in $\mathrm{m}, \beta_{3}=-2.91, \beta_{4}=2.19$, $\beta_{5}=0.756$ and $\beta_{6}=0.187$. For 158 of the studied trees, $\mathrm{WSG}_{i}$ had been measured in a companion study (see methods in Stahl et al., 2010). For the remaining 98 trees, we assigned the mean WSG of its species from the data of Stahl et al. (2010). If the $\mathrm{WSG}_{i}$ of the species was still missing, then we used the databases from Baraloto et al. (2010) and Rutishauser et al. (2010) to complete them.

The wood production at the time $t\left(\Delta \mathrm{AGB}_{i, t}\right)$ was computed as the difference of $\mathrm{AGB}_{i}$ between $t$ and $t-1$. The mean wood production of our sampled population for each census time $t$ was computed with the number of trees $\left(n_{\mathrm{t}}\right)$ at the census time $t$. Note that the calculated value of wood production cannot be used to estimate the monthly value of wood production per ha. However, in this study the absolute wood production per ha value was of secondary importance as we were more interested in the seasonal variation of wood production.

$$
\begin{aligned}
& \Delta \mathrm{AGB}_{i, t}=\mathrm{AGB}_{i, t}-\mathrm{AGB}_{i, t-1} \\
& \Delta \mathrm{AGB}_{\text {paracou }, t}=\frac{\sum_{i=1}^{n_{\mathrm{t}}} \Delta \mathrm{AGB}_{i, t}}{n_{\mathrm{t}}}
\end{aligned}
$$

We calibrated a monthly wood production model with the mean wood production of our sampled population and the climate variable of the CRU data set (Table 1) for the pixel of Paracou in a linear framework. To match the timescale of the MODIS data, climate data and the mean wood production of Paracou $\left(\triangle \mathrm{AGB}_{\text {paracou }, t}\right)$ were linearly interpolated to the MODIS time $t_{\mathrm{m}}\left(\Delta \mathrm{AGB}_{\mathrm{paracou}, t_{\mathrm{m}}}\right)$ :

$$
\begin{aligned}
\log \left(\Delta \mathrm{AGB}_{\text {paracou }, t_{\mathrm{m}}}+1\right) & =\alpha_{0}+\alpha_{1} \times \text { pre }_{t_{\mathrm{m}}}+\alpha_{2} \times \text { pet }_{t_{\mathrm{m}}} \\
& +\alpha_{3} \times \mathrm{tmp}_{t_{m}}+\alpha_{4} \times \mathrm{tmn}_{t_{m}} \\
& +\alpha_{5} \times \operatorname{tmx}_{t_{\mathrm{m}}}+\alpha_{6} \times \operatorname{cld}_{t_{\mathrm{m}}} \\
& +\alpha_{7} \times \operatorname{vap}_{t_{\mathrm{m}}}+\varepsilon
\end{aligned}
$$

where $\Delta \mathrm{AGB}_{\text {paracou, } t_{\mathrm{m}}}$ is the wood production for the MODIS time $t_{\mathrm{m}}, \alpha_{0}$ is the intercept of the model, $\alpha_{1, \ldots, 7}$ are the parameters of the climate drivers and $\varepsilon$ the error of the model assumed normal. We modelled the logarithm of growth instead of growth itself because our data showed a strong heteroscedasticity.

In a second step, we applied this model to predict the wood production $\left(\overline{\Delta \mathrm{AGB}_{p, t_{\mathrm{m}}}}, \mathrm{Eq} .5\right)$ for MODIS pixel $p$ with the CRU climate variable (Table 1) at the MODIS time $t_{\mathrm{m}}$ :

$$
\begin{aligned}
\overline{\log \left(\Delta \mathrm{AGB}_{p, t_{\mathrm{m}}}+1\right)} & =\alpha_{0}+\alpha_{1} \times \operatorname{pre}_{p, t_{\mathrm{m}}}+\alpha_{2} \times \operatorname{pet}_{p, t_{\mathrm{m}}} \\
& +\alpha_{3} \times \operatorname{tmp}_{p, t_{\mathrm{m}}}+\alpha_{4} \times \operatorname{tmn}_{p, t_{\mathrm{m}}} \\
& +\alpha_{5} \times \operatorname{tmx}_{p, t_{\mathrm{m}}}+\alpha_{6} \times \operatorname{cld}_{p, t_{\mathrm{m}}} \\
& +\alpha_{7} \times \operatorname{vap}_{p, t_{\mathrm{m}}} .
\end{aligned}
$$

\subsubsection{Image processing}

Using MRTtools, EVI, VI_Quality and pixel_reliability were extracted from the MODIS MOD13Q1 granule in .hdf format, resized to latitude of $2-6^{\circ} \mathrm{N}$ and longitude of -55 to $-51^{\circ} \mathrm{W}$, and converted to GeoTIFF images. On these images, we selected only the MODIS pixels containing forest, as defined by the five forest classes of Gond et al. (2011): low dense forest, high forest with regular canopy, high forest with disrupted canopy, mixed high and open forest, and open forest and Euterpe palm forest. We determined the validity of each 16-day composite EVI value of a land pixel using the methodology used and described in Samanta et al. (2010, Auxiliary materials). The selection was made by excluding pixel quality flags, clouds, cloud shadows, aerosol climatology and high aerosols. Pixels with the following quality flags were deemed "valid" (all other quality flags were ignored). MODIS Land quality assessment ("MODLAND_QA") evaluate and document the scientific quality of the MODLand product. The MODIS vegetation indices usefulness index ("VI usefulness") is a higher resolution quality indicator than the "MODLAND_QA" and its value for a pixel is determined from several conditions, including (1) aerosol quantity, (2) atmospheric correction conditions, (3) cloud cover, (4) shadow and (5) sun-target-viewing geometry. Here, the "MODLAND_QA" flag must be equal to 0 (good quality) 
Table 1. Description of the CRU climate data for the period 20072009.

\begin{tabular}{lll}
\hline Symbol & Climate variable & Unit \\
\hline pre & precipitation & $\mathrm{mm}$ \\
cld & cloud cover & $\%$ \\
pet & potential evapotranspiration & $\mathrm{mm}$ \\
tmp & mean temperature & ${ }^{\circ} \mathrm{C}$ \\
tmn & minimal temperature & ${ }^{\circ} \mathrm{C}$ \\
tmx & maximal temperature & ${ }^{\circ} \mathrm{C}$ \\
vap & vapour pressure & $\mathrm{hPa}$ \\
\hline
\end{tabular}

or 1 (check other quality assessment flags, QA). "VI usefulness" flags must be equal to 11 or less. "Adjacent cloud detected", "mixed clouds" and "possible shadow" flag values must be equal to 0 . The "aerosol quantity" flag must equal 1 (low aerosol) or 2 (average aerosol).

We estimated the value of EVI for the pixels excluded in the previous selection, $\mathrm{EVI}_{p_{\text {excluded }}, t_{\mathrm{m}}, \text { type. }}$. The estimation was made by assigning to the pixel missing an EVI value the mean EVI value of the $k$ neighbour valid pixels of the same forest type (type) in a square of side $40 \mathrm{~km}$, weighted by the inverse distance (dist) (Eq. 6):

$\overline{\mathrm{EVI}_{p_{\text {excluded }}, t_{\mathrm{m}}, \text { type }}}=\frac{\sum_{i=1}^{k} \operatorname{EVI}_{p_{\text {valid, },}, t_{\mathrm{m}}, \text { type }} \times\left(1 / \text { dist }_{k}\right)}{\sum_{i=1}^{k}\left(1 / \text { dist }_{k}\right)}$.

\subsubsection{Seasonality analysis}

To detect, estimate and test seasonal patterns in the EVI time series, we used temporal regression models from the R package "season" (Barnett and Dobson, 2010). The model is fitted using a sine and cosine term that together describes the sinusoid. These parameters are added to a generalized linear model to explain EVI data and test the existence of a seasonal pattern. The existence of a seasonal pattern was determined by the zero test based on Snedecor's F statistic. This method is called the cosinor test. Leaf maturity was define as the date at which EVI is maximum, from phenological phases of vegetation dynamics at annual timescales described in Zhang et al. (2003) using the MODIS vegetation index. Comparisons of LAI values per plots between dry (September 2010 and 2011) and wet season (March 2011 and 2012) were performed using a Student's $t$ test.

We computed cross-correlation coefficients between EVI,

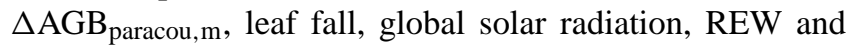
temperature to determine the maximum correlations, positive and negative (cor+ and cor-), and lagged times corresponding to these maximums (lag cor+ and lag cor-) between the times series. As our time series have an annual seasonality, we choose a maximum lag of 185 days. For the construction of the time series, we used the mean of EVI and $\triangle \mathrm{AGB}$ of the pixels corresponding to the forest type of Paracou at each of the MODIS times, and all the variables were then linearly approximated at a daily scale. The level of statistical significance for the maximum positive and negative correlations (cor+ and cor-) was computed by a bootstrap procedure. We randomly reordered the values of one of the time series, computed and stocked the cross-correlation coefficients and repeated this operation 1000 times. Then the cross correlations of the original variable were compared to the distribution of the cross correlations with the randomly reordered variable. The null hypothesis of uncorrelated original variables was rejected at a level of $0.05 \%$ if the cross correlation of the original variables was outside the $(0.025,0.975)$ quantiles of the empirical distribution of the randomly reordered cross correlations.

All analyses were performed using the $\mathrm{R}$ project software (http://www.r-project.org/).

\section{Results}

\subsection{Wood production}

The wood production model reproduced the general trend of the data well $\left(R^{2}=0.72\right.$, RMSE $\left.=0.385\right)$ (Table 2$)$. The modelled wood production showed a strong seasonality (Fig. 3a). Wood production increased from its lowest value in the dry season to its highest annual values at the beginning of the rainy season in 3.3 months (Table 3). However, production began to decline before the end of the wet season, in the middle of July. A decline in wood production was observed during the transition between the wet and the dry season (July to September) and during the dry season (September to December). Mean value of wood production is $1.35 \pm 0.85 \mathrm{~kg}$ tree $^{-1}$ month $^{-1}$ (Table 3).

\subsection{Enhanced vegetation index}

The EVI signal also exhibits a strong seasonality, and this signal has a similar pattern of variation among all five different types of forests found in French Guiana (Figs. 2 and 3b). Mean EVI for the forest type of Paracou increased by 24.3 to $31.7 \%$ between the lowest and highest values in a year (Table 3). The cosinor test indicated a significant seasonality for all the EVI pixels of French Guiana as well as for each forest type with $P<0.05$ (Table 4). The amplitude of the sinusoid is 0.03 with a phase (high point) in November and a low point in May. The temporal pattern represents an increase in EVI during the dry season with a maximum reached at the onset of the wet season (December to January) followed by a slow decrease during the wet season (Fig. 3b).

\subsection{Litterfall and LAI}

Litterfall is produced throughout the year, and at the onset of the dry season (late August-September) a peak of litterfall is observed (Fig. 3c and Table 3). The mean annual value of litterfall for the three inventory plots is 
Table 2. Model parameters, standard errors and $t$ values of the biomass production model calibrated with the field measurements of wood production in the Paracou forest.

\begin{tabular}{lrrrr}
\hline & Estimate & Std. Error & $t$ value & $\operatorname{Pr}(>|t|)$ \\
\hline (Intercept) & 8.8610 & 2.4690 & 3.59 & 0.0016 \\
pre & -0.0004 & 0.0004 & -1.05 & 0.3051 \\
pet & -0.0125 & 0.0078 & -1.59 & 0.1244 \\
tmp & 0.7350 & 1.2418 & 0.59 & 0.5597 \\
tmn & -0.3149 & 0.6208 & -0.51 & 0.6167 \\
tmx & -0.6439 & 0.6325 & -1.02 & 0.3193 \\
cld & -0.0191 & 0.0072 & -2.66 & 0.0140 \\
vap & 0.0639 & 0.0683 & 0.94 & 0.3593 \\
\hline
\end{tabular}

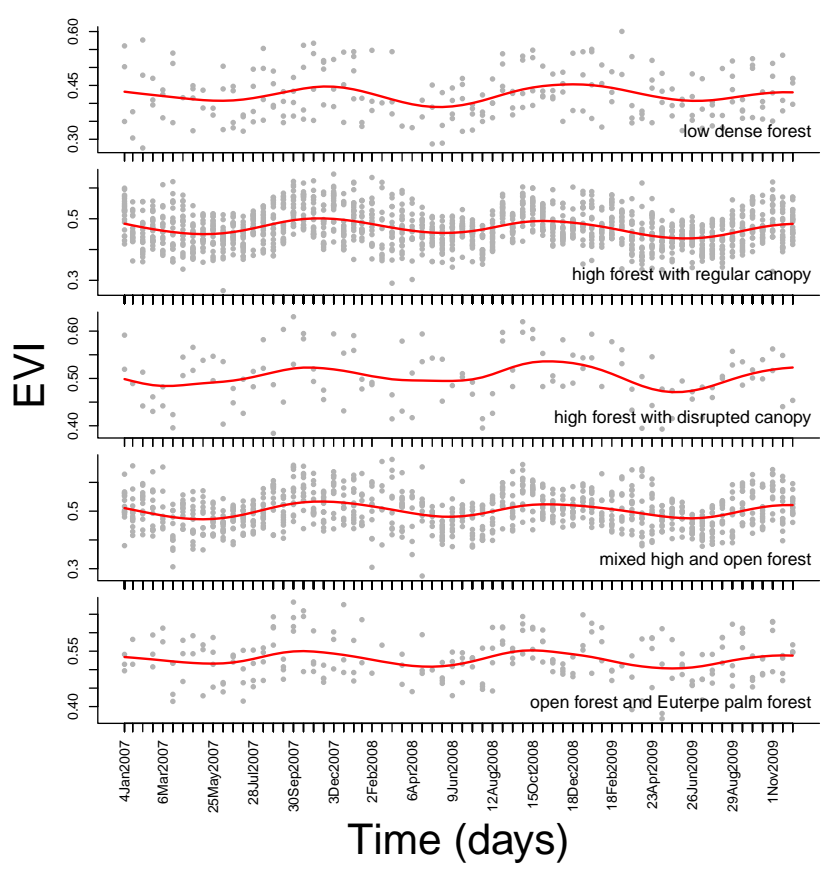

Fig. 2. Evolution of EVI values across French Guianan forest types. Each point represent the EVI value for the points of the $0.5^{\circ} \times 0.5^{\circ}$ CRU grid. Lines were fitted with a cubic smoothing spline. The forest type "high forest with regular canopy" corresponds to the type of Paracou.

$3.56 \pm 1.425 \mathrm{MgCha}^{-1} \mathrm{yr}^{-1}$ (Table 3). The value of LAI (mean $\pm \mathrm{SD}$ ) for the studied plots was $6.2 \pm 0.62$. The values of LAI were not statistically different between the dry and the wet seasons $(t=0.2675, \mathrm{df}=9.869, p$ value $=0.79)$ (see Fig. 3f in Rowland et al., 2013).

\subsection{Associations between EVI, litterfall, wood production and climate}

At the onset of the dry season, EVI increased when the peak of litterfall was observed (Fig. 3c). Peaks of EVI occurred 1 month after litterfall peak (31 days, Table 5). The peak

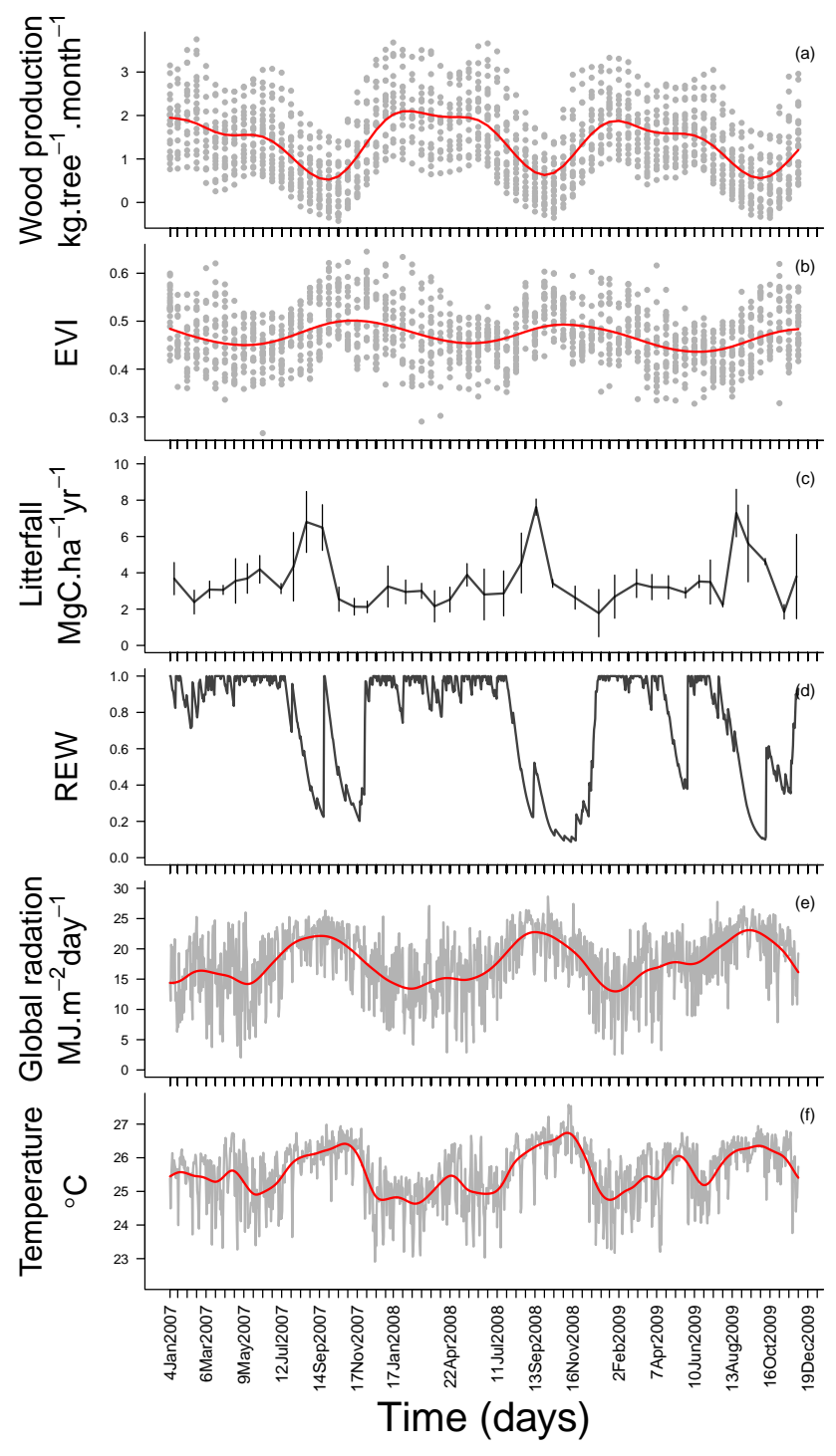

Fig. 3. Evolution of wood production and EVI corresponding to the forest type of Paracou. Litterfall production $( \pm S D)$, relative extractable water (REW; Wagner et al., 2010a), global radiation and mean daily temperature are measured in the Paracou experimental site. Points represent predicted wood production (a) and EVI values (b) of the MODIS pixels for the points of the $0.5^{\circ} \times 0.5^{\circ} \mathrm{CRU}$ grid for the type of forest of Paracou. Lines in (a), (b), (e) and (f) were fitted with a cubic smoothing spline.

of litterfall occurred when global radiation was maximum (Fig. 3e), and the peaks of litterfall and radiation occurred in a period of less than 1 month (Table 5). In the middle of the dry season (October to November), EVI was at its maximum and wood production at its minimum (Fig. 3). EVI and wood production have a significant negative cross correlation; the maximum negative correlation occurred with a lag of 1.5 months (Table 5). In October to November, REW, an index of soil water availability for tress (Wagner et al., 2010a, 
Table 3. Mean and standard deviation for wood production (predictions for the pixels of MODIS corresponding to the forest type of Paracou), enhanced vegetation index (EVI) corresponding to the forest type of Paracou, and litterfall measured in the three studied plots at Paracou. Mean and standard deviation are given for different specifications: for each year, for the census with the lowest mean value, for the census with the highest value and for the entire study period. Date is the date of the census for the lowest and the highest mean of the considered variable.

\begin{tabular}{|c|c|c|c|c|}
\hline Variable & Period & Specification & Date & Mean \pm SD \\
\hline \multirow{10}{*}{$\begin{array}{l}\text { Wood production } \\
\mathrm{kg} \text { tree }^{-1} \text { month }^{-1}\end{array}$} & 2007 & annual & & $1.29 \pm 0.833$ \\
\hline & 2007 & lowest & 16 Oct & $0.29 \pm 0.521$ \\
\hline & 2007 & highest & $18 \mathrm{Feb}$ & $2.16 \pm 0.818$ \\
\hline & 2008 & annual & & $1.48 \pm 0.908$ \\
\hline & 2008 & lowest & 15 Oct & $0.37 \pm 0.499$ \\
\hline & 2008 & highest & 17 Jan & $2.32 \pm 0.739$ \\
\hline & 2009 & annual & & $1.29 \pm 0.795$ \\
\hline & 2009 & lowest & 16 Oct & $0.37 \pm 0.553$ \\
\hline & 2009 & highest & 17 Jan & $2.15 \pm 0.574$ \\
\hline & 2007-2009 & period & & $1.35 \pm 0.85$ \\
\hline \multirow{10}{*}{ EVI } & 2007 & annual & & $0.47 \pm 0.061$ \\
\hline & 2007 & lowest & $23 \mathrm{Apr}$ & $0.43 \pm 0.048$ \\
\hline & 2007 & highest & $3 \mathrm{Dec}$ & $0.55 \pm 0.052$ \\
\hline & 2008 & annual & & $0.47 \pm 0.056$ \\
\hline & 2008 & lowest & $27 \mathrm{Jul}$ & $0.41 \pm 0.038$ \\
\hline & 2008 & highest & 29 Sep & $0.54 \pm 0.041$ \\
\hline & 2009 & annual & & $0.46 \pm 0.056$ \\
\hline & 2009 & lowest & $12 \mathrm{Jul}$ & $0.41 \pm 0.035$ \\
\hline & 2009 & highest & $1 \mathrm{Nov}$ & $0.51 \pm 0.066$ \\
\hline & 2007-2009 & period & & $0.47 \pm 0.058$ \\
\hline \multirow{10}{*}{$\begin{array}{l}\text { Litterfall } \\
\mathrm{MgCha}^{-1} \mathrm{yr}^{-1}\end{array}$} & 2007 & annual & & $3.66 \pm 1.446$ \\
\hline & 2007 & lowest & $4 \mathrm{Dec}$ & $2.12 \pm 0.319$ \\
\hline & 2007 & highest & $23 \mathrm{Aug}$ & $6.8 \pm 1.678$ \\
\hline & 2008 & annual & & $3.34 \pm 1.466$ \\
\hline & 2008 & lowest & $30 \mathrm{Dec}$ & $1.78 \pm 1.302$ \\
\hline & 2008 & highest & $15 \mathrm{Sep}$ & $7.61 \pm 0.451$ \\
\hline & 2009 & annual & & $3.68 \pm 1.451$ \\
\hline & 2009 & lowest & 9 Nov & $1.85 \pm 0.4$ \\
\hline & 2009 & highest & $20 \mathrm{Aug}$ & $7.29 \pm 1.308$ \\
\hline & 2007-2009 & period & & $3.56 \pm 1.425$ \\
\hline
\end{tabular}

Table 4. Seasonality of EVI estimated with cosinor analysis for the forest types of French Guiana. $N$ is the number of observations used in the analysis. Amplitude is the difference between the higher and the lower points of the sinusoid fitted in the cosinor analysis. Phase and low phase are respectively the month of highest/lowest the value of EVI according to the sinusoid fitted in the cosinor analysis. A $P$ value $<0.05$ indicates that a statistically significant existence of a seasonal pattern cannot be rejected.

\begin{tabular}{lrcllc}
\hline Forest type & $N$ & amplitude & phase & low phase & $P$ value \\
\hline low dense forest/included savanna & 224 & 0.031 & Month $=$ Dec, day $=6$ & Month = Jun, day $=7$ & $<0.05$ \\
high forest with regular canopy & 1455 & 0.032 & Month $=$ Nov, day $=23$ & Month = May, day $=24$ & $<0.05$ \\
high forest with disrupted canopy & 125 & 0.028 & Month $=$ Nov, day $=10$ & Month = May, day $=11$ & $<0.05$ \\
mixed high and open forest & 916 & 0.035 & Month $=$ Nov, day $=24$ & Month = May, day $=25$ & $<0.05$ \\
open forest and Euterpe palm forest & 217 & 0.026 & Month $=$ Nov, day $=6$ & Month = May, day $=7$ & $<0.05$ \\
all forest types & 2937 & 0.032 & Month = Nov, day =22 & Month = May, day $=23$ & $<0.05$ \\
\hline
\end{tabular}


Table 5. Cross correlation between the mean predicted wood production for the pixels of MODIS corresponding to the forest type of Paracou ( $\triangle \mathrm{AGB}$ ); the mean enhanced vegetation index (EVI) corresponding to the forest type of Paracou; relative extractable water (REW) at Paracou; litterfall measured at Paracou; and mean temperature (tmp) and global radiation ( $\mathrm{Rg}$ ), both measured from the flux tower at Paracou. cor+ and cor- are the maximum positive and negative cross-correlation coefficient between the two time series, lag cor+ and lag cor - are the respective time lags corresponding to the maximum positive and negative coefficient of correlation (cor+ and cor-) in days and $\mathrm{CI}+$ and $\mathrm{CI}-$ are the $95 \%$ interval of the null hypothesis for cor+ and cor-. If the correlation coefficient falls in the $95 \%$ interval, we cannot reject the null hypothesis of uncorrelated variables. As an example, the maximum positive correlation coefficient between $\triangle \mathrm{AGB}$ and EVI is 0.71. This correlation is significant, i.e. $>$ to the positive confidence interval (CI+) of 0.059 . The time lag of 109.00 (lag cor+) indicates that the peak of $\triangle \mathrm{AGB}$ occurred 109 days after the peak of EVI.

\begin{tabular}{|c|c|c|c|c|c|c|c|}
\hline $\operatorname{var}_{1}$ & $\operatorname{var}_{2}$ & cor+ & $\mathrm{CI}+$ & lag cor+ & cor- & CI- & lag cor- \\
\hline$\Delta \mathrm{AGB}$ & EVI & 0.71 & $-0.059-0.059$ & 109.00 & -0.54 & $-0.06-0.057$ & -47.00 \\
\hline$\Delta \mathrm{AGB}$ & litterfall & 0.32 & $-0.059-0.054$ & -95.00 & -0.66 & $-0.056-0.059$ & 29.00 \\
\hline$\Delta \mathrm{AGB}$ & REW & 0.80 & $-0.06-0.064$ & -17.00 & -0.39 & $-0.058-0.052$ & 121.00 \\
\hline$\Delta \mathrm{AGB}$ & $\operatorname{tmp}$ & 0.26 & $-0.051-0.052$ & -140.00 & -0.59 & $-0.058-0.06$ & -8.00 \\
\hline$\Delta \mathrm{AGB}$ & $\mathrm{Rg}$ & 0.27 & $-0.052-0.055$ & -166.00 & -0.56 & $-0.064-0.063$ & 10.00 \\
\hline EVI & litterfall & 0.36 & $-0.061-0.06$ & 31.00 & -0.51 & $-0.061-0.06$ & -61.00 \\
\hline EVI & REW & 0.59 & $-0.057-0.054$ & -131.00 & -0.54 & $-0.056-0.062$ & 30.00 \\
\hline EVI & $\operatorname{tmp}$ & 0.30 & $-0.062-0.06$ & 38.00 & -0.45 & $-0.057-0.057$ & -127.00 \\
\hline EVI & $\mathrm{Rg}$ & 0.36 & $-0.056-0.06$ & 48.00 & -0.43 & $-0.057-0.061$ & -93.00 \\
\hline litterfall & REW & 0.41 & $-0.057-0.061$ & 67.00 & -0.54 & $-0.058-0.059$ & -45.00 \\
\hline litterfall & tmp & 0.41 & $-0.059-0.062$ & -46.00 & -0.24 & $-0.06-0.054$ & 75.00 \\
\hline litterfall & $\operatorname{Rg}$ & 0.36 & $-0.061-0.062$ & -20.00 & -0.20 & $-0.064-0.059$ & 126.00 \\
\hline REW & $\operatorname{tmp}$ & 0.31 & $-0.054-0.055$ & -119.00 & -0.63 & $-0.06-0.058$ & 0.00 \\
\hline REW & $\mathrm{Rg}$ & 0.28 & $-0.052-0.055$ & -124.00 & -0.49 & $-0.06-0.063$ & 22.00 \\
\hline tmp & $\mathrm{Rg}$ & 0.66 & $-0.056-0.06$ & 0.00 & -0.22 & $-0.059-0.056$ & 182.00 \\
\hline
\end{tabular}

2012), reached its lowest values (Fig. 3d). As previously observed in Wagner et al. (2012), REW is highly and directly correlated to wood production and this association is statistically significant (Table 5). Mean temperature (tmp) has a significant positive correlation with global radiation without any time lag, and shows the same pattern of correlation than global radiation toward wood production (Table 5).

At the beginning of the wet season (December to January), EVI remained high, but wood production sharply increased to reach its maximal value in less than two months. The increase of wood production followed the trend of increasing REW in the early wet season (Fig. 3d). Peaks of EVI and wood production showed a positive correlation with a lag of 3.5 months (109 days, Table 5). During the rainy season (February to June), wood production as well as EVI values slowly decreased. In July, we observed a strong decline in wood production, while EVI started to increase. Then EVI reached its maximum, and the annual cycle started again. The link between wood production and EVI exhibited a regular annual hysteresis (Fig. 4). The highest wood production was observed for relatively high values of EVI during the early wet season. Surprisingly, EVI showed a substantial inter-annual variability (Fig. 4).

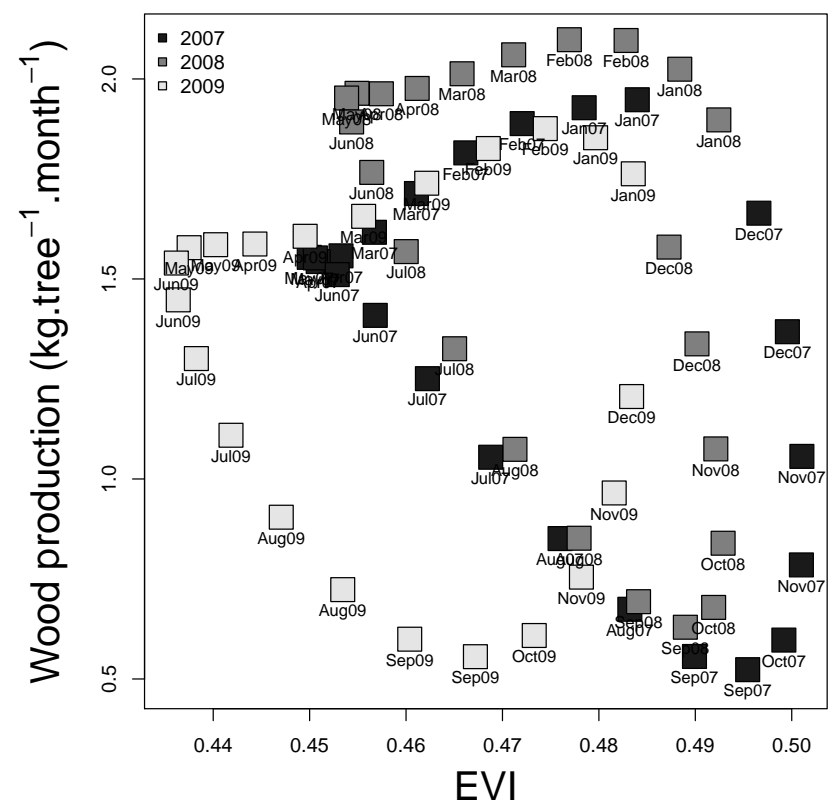

Fig. 4. Hysteresis of the correlation between wood production and EVI corresponding to the forest type of Paracou for the period 2007-2009. Wood production and EVI values were estimates from a cubic smoothing spline fitted on the raw data. 


\section{Discussion}

The mean annual productivity of leaves and wood at Paracou are respectively $2.4 \pm 1.4$ and $2.2 \pm 0.4 \mathrm{MgCha}^{-1} \mathrm{yr}^{-1}$ (Bonal et al., 2008; De Weirdt et al., 2012; Rutishauser et al., 2010; Wagner et al., 2010b). Here, we showed that these two biomass fluxes, which have the same range in terms of $\mathrm{C}$ amount, occurred separately in time. In the following paragraphs, we discuss the dynamics and potential drivers of these fluxes and of the interactions between them.

\subsection{Leaf phenology}

The so-called "greening" of the forest observed with EVI data was related to the leaf production but did not constitute a direct indicator of wood production (Fig. 4). At Paracou, as expected for an evergreen tropical forest, leaf litter is produced throughout the year, indicating that the trees have sufficient carbon supply and adequate climate to produce new leaves even at the beginning of the dry season, when litterfall peaks (Fig. 3c). In contrast to EVI and litterfall, no seasonal pattern was found in LAI, and LAI was not therefore considered as a reliable indicator of leaf renewal. As previously observed at Paracou, the increase in litterfall did not induce major changes in LAI during dry periods (Bonal et al., 2008). However, it is possible that there was a short-term change in the LAI following the litter-fall pulse and therefore higher resolution LAI data is necessary (Rowland et al., 2013). Leaves are an important, but often neglected, part of the short-term forest carbon balance (Malhi and Grace, 2000). In this study, litterfall averaged $2.4 \pm 1.38 \mathrm{MgCha}^{-1} \mathrm{yr}^{-1}$ (Bonal et al., 2008; De Weirdt et al., 2012), a little more than half of the $4.351 \pm 0.955 \mathrm{MgCha}^{-1} \mathrm{yr}^{-1}$ (Chave et al., 2010) observed, on average, for old-growth tropical rainforests in Amazonia. However, these values of leaf production represent very short-term carbon pools as all leaves are expected to fall after a while and, contrary to wood production, cannot be directly connected to long-term variation of the biomass stock. Recent works throughout Amazonia have estimated a large range of leaf residence time, from 6 to 36 months, with a lifespan distribution suggesting a pronounced annual regularity (Caldararu et al., 2012). These authors found that the average leaf lifespan increases from the eastern Amazon, where leaves are typically short-lived, to the evergreen central Amazon Basin.

The ecological significance of a so-called "forest greening" (Huete et al., 2006) in French Guiana (Table 4) is leaf production, which mainly occurs in the dry season, when old leaves are replaced. Recent works have highlighted that during the dry season, EVI was sensitive to view-illumination effects due to the variation of the solar zenith angle in a location close to Xingu Indigenous Park in Brazil, $13^{\circ} 12^{\prime} 22^{\prime \prime} \mathrm{S}$ and $52^{\circ} 20^{\prime} 59^{\prime \prime} \mathrm{W}$ (Galvao et al., 2013; Moura et al., 2012). Nevertheless, we assume that this potential bias is reduced in our study due to a closer distance to the equator $\left(5^{\circ} 18^{\prime} \mathrm{N}\right)$.
Our results confirm the link between intra-annual variations of EVI and field observations of leaf phenology (Fig. 3) and suggest that most leaves are shed when new ones appear. These variations in phenology and EVI coincided with seasonal peaks in solar irradiance in Amazonia (Wagner et al., 2012; Bonal et al., 2008; Huete et al., 2006; Saleska et al., 2003; Wright and Vanschaik, 1994; Sabatier and Puig, 1986; Pennec et al., 2011; De Weirdt et al., 2012). Even if leaf fall is important throughout the year, it reaches its maximum when the peak of irradiance occurs in Paracou (Bonal et al., 2008; Sabatier and Puig, 1986; Loubry, 1994). Moreover, the EVI signal is synchronous among all forest types of French Guiana (Fig. 2), which suggests that irradiance could be the general driver of leaf fall in French Guiana. Recently, the extreme 2005 drought in Amazonia was suspected to impact leaf production (Saleska et al., 2007). No statistical correlation has been found so far between drought severity and greenness changes (Samanta et al., 2010). The phenological consequences of long-term changes in solar radiation or alterations in diffuse/direct components still remain an open question in tropical forests (Lewis et al., 2004). However, we know that the frequency of drought events should increase (Solomon et al., 2007, 2009), and as a consequence cloudiness should decrease while irradiance should increase (Nemani et al., 2003; Arias et al., 2011). Further analysis is needed to understand the link between leaf dynamics and climate in order to decipher whether the trigger of leaf fall is the peak of irradiance, an intrinsic biological clock, another climate driver sensitive to climate change, or all these factors combined. The use of multiple sites with different phase between high rainfall and high irradiance could help disentangle physiological and climate effects on leaf and wood production.

\subsection{Wood production}

The seasonality of wood production was consistent with observations from other tropical forests, even those tropical forests without any month with precipitation below $100 \mathrm{~mm}$ (Clark et al., 2010; Grogan and Schulze, 2012; Wagner et al., 2012; Nepstad et al., 2002). This intra-annual seasonality cannot be considered as the sole result of bark shrinkage and swelling (Fig. 1). Indeed, both trees with low (0.19$0.41 \mathrm{~g} \mathrm{~cm}^{-3}, 58$ trees) and high $\left(0.59-0.83 \mathrm{~g} \mathrm{~cm}^{-3}, 58\right.$ trees $)$ bark density exhibited similar seasonal variations in wood production, indicating that variations in cambial activity explained most of the variations in circumference. Here, we showed that wood production has a complex link with the socalled "forest greening". First, wood production decreased when EVI increased during the transition between the wet and the dry season (June to September). Second, wood production increased in the early wet season, while EVI remained constant at its highest values. Finally, wood production slowly decreased during the wet season, while EVI dropped to its lowest values (Fig. 4). The asynchronism 
between leaf and wood production could reflect a time lag in the use of carbohydrates (3.5 months, Table 5) synthesized during the whole year but allocated into short-lived pools (leaves) in the dry season and into long-lived pools (wood) only during the wet season, as already observed in the forest of Parque Natural Metropolitano, Panama (Wurth et al., 2005). If we make the assumption that wood production occurs mainly when leaves are fully mature, then the time lag between peaks of EVI and wood production (109 days, Table 5) indicates the mean time needed for leaves to become fully mature.

Three main climate variables have been demonstrated to impact intra-annual wood production: (i) soil water availability, (ii) irradiance and (iii) temperature. (i) The highest wood production is observed after the greening in the early wet season, when water availability is high, (Fig. 3) and when new leaves are fully matured, i.e. ecosystem photosynthetic capacity is at its maximum (Stahl et al., 2013). Soil water availability strongly impacts wood productivity as directly observed in tropical forests (Wagner et al., 2012; Nath et al., 2006; Baker et al., 2003) and as deduced from experimental forest droughts (Nepstad et al., 2002; Lola da Costa et al., 2010). (ii) Wood production could be indirectly linked to irradiance via a shift in resource allocation from wood to leaves during the peak of irradiance in the early dry season (Fig. 3). This is consistent with the results of Huete et al. (2006), which indicated a strong influence of radiation on leaf phenology, and previous ground-based studies in tropical forests which have highlight an exchange of leaves and a reduced wood production during drier months (O'Brien et al., 2008; Rice et al., 2004; Krepkowski et al, 2011). However, our results do not support a predominant role of radiation in forest productivity expressed as wood production (Fig. 3). Some authors have further suggested that high values of irradiance could drive the leaf production cycle, as observed in seasonal and aseasonal forests (Zalamea and Gonzalez, 2008; Myneni et al., 2007; Hutyra et al., 2007). (iii) At La Selva (Clark et al., 2010), annual growth was found to be sensitive to variations of $1-2{ }^{\circ} \mathrm{C}$ in mean annual night-time temperature. In our site, mean daily temperature is highly correlated to daily global radiation (Table 5). Temperatures remain rather high (daily mean temperature never less than $23^{\circ} \mathrm{C}$ ) and seasonal variations in these temperatures remain rather limited (Fig. 3f). Here, we assume that the effect of temperature seen on wood production (Table 5) is more likely due to its correlation with global radiation rather than an effect on a biological process. Investigating the effects of temperature on the physiology of tropical forest trees (Chambers and Silver, 2004; Lloyd and Farquhar, 2008) is today of primary importance given increases expected over the next century (Solomon et al., 2007; Malhi et al., 2009).

\subsection{Does leaf production impact wood production?}

Our results highlight a synchronism between old leaves falling, new leaf production and reduced wood production (Fig. 3). A few months later the peak of EVI (3.5 months, Table 5), maximal wood production correlates with high value of water availability and high EVI signal (Fig. 3). Seasonal variations in wood production also exist even in a very constant environment without a dry season, like in La Selva, Costa Rica (Clark et al., 2010), supporting the idea of an annual regulation not induced by drought. In the same way, Tapajós National Forest maintains high transpiration and photosynthesis in the dry season while wood production declines (Verbeeck et al., 2011; Figueira et al., 2011). As we observed the same seasonal pattern of EVI in all the forest types of French Guiana (Fig. 2), we can hypothesize that for all these forest types, leaf renewal follows the same seasonal pattern as the leaf renewal of the Paracou forest type. Our results of the dynamic and interactions of leaf and wood production in the dry season (Figs. 3 and 4) could be explained by the different costs or limiting factors of leaf or wood tissues production. Some studies have reported that evergreen species in seasonally dry environments accumulate carbohydrates during the dry season because photosynthesis continues while wood production ceases (Wurth et al., 2005) and that deciduous species accumulate carbohydrates at the onset of the dry season to support respiration costs when they are leafless (Poorter and Kitajima, 2007; Janzen and Wilson, 1974). Indeed, the cost of wood production is high (to produce $1 \mathrm{~g}$ of trunk of Eucalyptus regnans, more than $1 \mathrm{~g}$ of glucose is needed; Kozlowski, 1992). In contrast to wood production, the cost of new leaf production, flowering or fruiting does not necessarily deplete non-structural carbohydrate (NSC) pools (Wurth et al., 2005). Even species flushing and fruiting during the dry season show high values of NSC, indicating that growth during the dry season is not carbon limited. We do not have any evidence of carbon limitation in the dry season at Paracou, but wood production could be limited by water availability as wood production is highly correlated with this variable (Table 5), previously reported as the main driver of tree growth with the same data set (Wagner et al., 2012). Understanding the NSC dynamic and how NSC concentrations are related to leaf phenology and wood production are current topics in forest ecophysiology. In temperate forests, Michelot et al. (2012) showed for two deciduous species, Fagus sylvatica L. and Quercus petraea (Matt.) Liebl., and an evergreen conifer, Pinus sylvestri, that the timing, duration and rate of wood production are related to leaf phenology and the dynamics of NSC. They found that leaf phenology, NSC storage and intra-annual growth were clearly different between species, highlighting their contrasting carbon allocation. Very recently, the seasonal dynamics and ages of stemwood NSC in temperate forest trees has been assessed by Richardson et al. (2013). These authors found that NSC were both highly dynamic and about a decade old. 
Their model with a two-pool structure (fast- and slow-cycling reserves) gave reasonable estimates of the size and mean residence time of the total NSC pool and greatly improved model predictions of inter-annual variability in the woody biomass increment. We should acknowledge that the existence itself of long-term and short-term cycles in NSC are largely ignored among researchers studying tropical trees. Such ecophysiological approaches are urgently needed to improve our understanding of intra-annual NPP.

\subsection{Scaling issues}

As this is a pioneer study, we have to acknowledge that spatial and temporal scaling of the data used here are critical for producing general predictions. In this study, we make the strong assumption that an average tree from our sample is representative of an average tree across the forest type of Paracou. As shown at Paracou in Wagner et al. (2010b), diameter growth, and hence woody biomass growth, can be estimated with relatively small sampling areas. For example, the coefficient of variations of diameter growth is $<20 \%$ for a surface of 0.5 ha censused every 2 yr. Furthermore, our sample is a mix of trees across seasonally flooded and terra firme habitats, typical of this forest type (Sabatier et al., 1997). However, we know that 256 trees will not totally reflect the complex forest structure and biomass. For this reason, we focus in this paper only on the seasonal variations of woody biomass growth. Another potential bias could be the use of data sets with different temporal resolution that lead us to use linear approximation. The result of this approximation could slightly influence the value and timing of the peaks and of the lowest points. However, here again, we are not interested by the absolute values of these variables but by the co-variation between EVI and woody growth at a seasonal scale. Additional studies are needed to fill the gap between improving knowledge from correlation studies and modelling for prediction.

\section{Conclusions}

Tropical forest productivity assessed either by inventorybased observations or satellite-based studies does not rely on similar biological processes (Anderson, 2012). Inventorybased studies catch wood production through secondary growth, while satellite studies based on EVI catch only a part of NPP related to leaf production. We pointed out the 3.5 month time lag between leaf production and wood production that probably reflects the change of carbon allocation in tropical trees during the year. This decoupling between the leaf renewal and the wood production seems associated to the seasonality of their respective assumed drivers at Paracou, irradiance and soil water availability. Some work remains to be done before we can understand what controls this time lag. To decipher whether this time lag is driven by endoge- nous biological or by exogenous climate drivers, pantropical analyses of inter-annual biomass production data coupled with EVI data and global climate data are needed. The use of multiple sites with different phases between high rainfall and high irradiance could enable researchers to disentangle physiological and climate effects on leaf and wood production. In the near future, new techniques for the study of chlorophyll content and photosynthetic activity by remote sensing will be available from airborne and space-borne sensors as well (e.g. the ESA-FLEX scientific mission; European Space Agency, 2008; Meroni et al., 2010; Delegido et al., 2011) and should give direct measurements of the production of carbohydrates by trees. As current IPCC scenarios predict an intensification of the dry period for the Guiana Shield and the Amazon during the 21st century (Solomon et al., 2007, 2009; Harris et al., 2008), further research is needed to decipher what shapes the forest productivity pattern. In the context of global change, a response to this question is urgently needed to predict the carbon balance of tropical forests for the next uncertain centuries.

Acknowledgements. Funding has been provided by the project Climfor (Fondation pour la Recherche sur la Biodiversité), the project Guyasim (European structural funding, PO-Feder) and by the Fapesp (Fundação de Amparo à Pesquisa do Estado de São Paulo, Grant number 13/14520-6). This work has also benefited from an "Investissement d'Avenir" grant managed by Agence Nationale de la Recherche (CEBA, ref. ANR-10-LABX-0025). This study has been possible thanks to the important field work realized at Paracou by B. Burban, J.-Y. Goret, J. Cazal, F. Bompy, J. Sermage and S. Thibaudeau.

Edited by: M. Williams

\section{References}

Allen, R., Smith, M., Pereira, L., and Perrier, A.: An update for the calculation of reference evapotranspiration, Journal of the ICID, 43, 35-92, 1994.

Anderson, L. O.: Biome-scale forest properties in Amazonia based on field and satellite observations, Remote Sens., 4, 1245-1271, doi:10.3390/rs4051245, 2012.

Arias, P. A., Fu, R., Hoyos, C. D., Li, W., and Zhou, L.: Changes in cloudiness over the Amazon rainforests during the last two decades: diagnostic and potential causes, Clim. Dynam., 37, 1151-1164, doi:10.1007/s00382-010-0903-2, 2011.

Asner, G., Townsend, A., and Braswell, B.: Satellite observation of El Nino effects on Amazon forest phenology and productivity, Geophys. Res. Lett., 27, 981-984, doi:10.1029/1999GL011113, 2000.

Asner, G., Nepstad, D., Cardinot, G., and Ray, D.: Drought stress and carbon uptake in an Amazon forest measured with spaceborne imaging spectroscopy, P. Natl. Acad. Sci. USA, 101, 60396044, doi:10.1073/pnas.0400168101, 2004.

Baccini, A., Goetz, S. J., Walker, W. S., Laporte, N. T., Sun, M., Sulla-Menashe, D., Hackler, J., Beck, P. S. A., Dubayah, R., 
Friedl, M. A., Samanta, S., and Houghton, R. A.: Estimated carbon dioxide emissions from tropical deforestation improved by carbon-density maps, Nat. Clim. Change, 2, 182-185, doi:10.1038/NCLIMATE1354, 2012.

Baker, T., Burslem, D., and Swaine, M.: Associations between tree growth, soil fertility and water availability at and regional scales in Ghanian tropical rain forest, J. Trop. Ecol., 19, 109-125, 2003.

Baraloto, C., Paine, C. E. T., Poorter, L., Beauchene, J., Bonal, D., Domenach, A.-M., Herault, B., Patino, S., Roggy, J.-C., and Chave, J.: Decoupled leaf and stem economics in rain forest trees, Ecol. Lett., 13, 1338-1347, doi:10.1111/j.14610248.2010.01517.x, 2010.

Barnett, A. and Dobson, A.: Analysing Seasonal Health Data, Springer, 2010.

Bonal, D., Bosc, A., Ponton, S., Goret, J. Y., Burban, B., Gross, P., Bonnefond, J. M., Elbers, J., Longdoz, B., Epron, D., Guehl, J. M., and Granier, A.: Impact of severe dry season on net ecosystem exchange in the neotropical rainforest of French Guiana, Glob. Change Biol., 14, 1917-1933, 2008.

Bradley, A. V., Gerard, F. F., Barbier, N., Weedon, G. P., Anderson, L. O., Huntingford, C., Aragao, L. E. O. C., Zelazowski, P., and Arai, E.: Relationships between phenology, radiation and precipitation in the Amazon region, Glob. Change Biol., 17, 2245-2260, doi:10.1111/j.1365-2486.2011.02405.x, 2011.

Brando, P. M., Goetz, S. J., Baccini, A., Nepstad, D. C., Beck, P. S. A., and Christman, M. C.: Seasonal and interannual variability of climate and vegetation indices across the Amazon, P. Natl. Acad. Sci. USA, 107, 14685-14690, doi:10.1073/pnas.0908741107, 2010.

Caldararu, S., Palmer, P. I., and Purves, D. W.: Inferring Amazon leaf demography from satellite observations of leaf area index, Biogeosciences, 9, 1389-1404, doi:10.5194/bg-9-13892012, 2012.

Chambers, J. Q. and Silver, W. L.: Some aspects of ecophysiological and biogeochemical responses of tropical forests to atmospheric change, Philos. T. Roy. Soc. B, 359, 463-476, 2004.

Chave, J., Navarrete, D., Almeida, S., Álvarez, E., Aragão, L. E. O. C., Bonal, D., Châtelet, P., Silva-Espejo, J. E., Goret, J.-Y., von Hildebrand, P., Jiménez, E., Patiño, S., Peñuela, M. C., Phillips, O. L., Stevenson, P., and Malhi, Y.: Regional and seasonal patterns of litterfall in tropical South America, Biogeosciences, 7, 43-55, doi:10.5194/bg-7-43-2010, 2010.

Clark, D. B., Clark, D. A., and Oberbauer, S. F.: Annual wood production in a tropical rain forest in NE Costa Rica linked to climatic variation but not to increasing $\mathrm{CO}_{2}$, Glob. Change Biol., 16, 747-759, doi:10.1111/j.1365-2486.2009.02004.x, 2010.

Delegido, J., Vergara, C., Verrelst, J., Gandia, S., and Moreno, J.: Remote estimation of crop chlorophyll content by means of highspectral-resolution reflectance techniques, Agron. J., 103, 18341842, doi:10.2134/agronj2011.0101, 2011.

De Weirdt, M., Verbeeck, H., Maignan, F., Peylin, P., Poulter, B., Bonal, D., Ciais, P., and Steppe, K.: Seasonal leaf dynamics for tropical evergreen forests in a process-based global ecosystem model, Geosci. Model Dev., 5, 1091-1108, doi:10.5194/gmd-51091-2012, 2012.

Doughty, C. E.: An In Situ Leaf and Branch Warming Experiment in the Amazon,Biotropica, 43, 658-665 doi:10.1111/j.17447429.2010.00746.x, 2011.
Doughty, C. E. and Goulden, M. L.: Are tropical forests near a high temperature threshold?, J. Geophys. Res.-Biogeo., 113, G00B07 doi:10.1029/2007JG000632, 2008.

Ekström, M., Jones, P. D., Fowler, H. J., Lenderink, G., Buishand, T. A., and Conway, D.: Regional climate model data used within the SWURVE project - 1: projected changes in seasonal patterns and estimation of PET, Hydrol. Earth Syst. Sci., 11, 1069-1083, doi:10.5194/hess-11-1069-2007, 2007.

Enquist, B. and Leffler, A.: Long-term tree ring chronologies from sympatric tropical dry-forest trees: individualistic responses to climatic variation, J. Trop. Ecol., 17, 41-60, 2001.

European Space Agency: ESA SP-1313/4 Candidate Earth Explorer Core Missions - Reports for Assessment: FLEX - FLuorescence EXplorer, Tech. rep., published by ESA Communication Production Office, Noordwijk, The Netherlands, available at: http://esamultimedia.esa.int/docs/SP1313-4_FLEX.pdf, 2008.

Fichtler, E., Clark, D., and Worbes, M.: Age and long-term growth of trees in an old-growth tropical rain forest, based on analyses of tree rings and C-14, Biotropica, 35, 306-317, doi:10.1111/j.1744-7429.2003.tb00585.x, 2003.

Figueira, A., Miller, S., de Sousa, C., Menton, M., Maia, A., da Rocha, H., and Goulden., M.: LBA-ECO CD-04 Dendrometry, km 83 Tower Site, Tapajos National Forest, Brazil, Data set, available at: http://daac.ornl.gov, Oak Ridge National Laboratory Distributed Active Archive Center, Oak Ridge, Tennessee, USA, doi:10.3334/ORNLDAAC/989, 2011.

Galvao, L. S., Breunig, F. M., dos Santos, J. R., and de Moura, Y. M.: View-illumination effects on hyperspectral vegetation indices in the Amazonian tropical forest, Int. J. Appl. Earth Obs., 21, 291-300, doi:10.1016/j.jag.2012.07.005, 2013.

Gao, X., Huete, A., Ni, W., and Miura, T.: Optical-biophysical relationships of vegetation spectra without background contamination, Remote Sens. Environ., 74, 609-620, doi:10.1016/S00344257(00)00150-4, 2000.

Gond, V., Freycon, V., Molino, J.-F., Brunaux, O., Ingrassia, F., Joubert, P., Pekel, J.-F., Prevost, M.-F., Thierron, V., Trombe, P.-J., and Sabatier, D.: Broad-scale spatial pattern of forest landscape types in the Guiana Shield, Int. J. Appl. Earth Obs., 13, 357-367, doi:10.1016/j.jag.2011.01.004, 2011.

Gourlet-Fleury, S., Guehl, J. M., and Laroussinie, O.: Ecology and management of a neotropical rainforest - lessons drawn from Paracou, a long-term experimental research site in French Guiana, Elsevier, 2004.

Graham, E. A., Mulkey, S. S., Kitajima, K., Phillips, N. G., and Wright, S. J.: Cloud cover limits net $\mathrm{CO}_{2}$ uptake and growth of a rainforest tree during tropical rainy seasons, P. Natl. Acad. Sci. USA, 100, 572-576, 2003.

Grogan, J. and Schulze, M.: The impact of annual and seasonal rainfall patterns on growth and phenology of emergent tree species in Southeastern Amazonia, Brazil, Biotropica, 44, 331340, doi:10.1111/j.1744-7429.2011.00825.x, 2012.

Harris, P. P., Huntingford, C., and Cox, P. M.: Amazon Basin climate under global warming: the role of the sea surface temperature, Philos. T. R. Soc. B, 363, 1753-1759, 2008.

Huete, A., Didan, K., Miura, T., Rodriguez, E., Gao, X., and Ferreira, L.: Overview of the radiometric and biophysical performance of the MODIS vegetation indices, Remote Sens. Environ., 83, 195-213, doi:10.1016/S0034-4257(02)00096-2, 2002. 
Huete, A. R., Didan, K., Shimabukuro, Y. E., Ratana, P., Saleska, S. R., Hutyra, L. R., Yang, W. Z., Nemani, R. R., and Myneni, R.: Amazon rainforests green-up with sunlight in dry season, Geophys. Res. Lett., 33, L06405 doi:10.1029/2005GL025583, 2006.

Hutyra, L. R., Munger, J. W., Saleska, S. R., Gottlieb, E., Daube, B. C., Dunn, A. L., Amaral, D. F., de Camargo, P. B., and Wofsy, S. C.: Seasonal controls on the exchange of carbon and water in an Amazonian rain forest, J. Geophys. Res.-Biogeo., 112, G03008, doi:10.1029/2006JG000365, 2007.

Janzen, D. and Wilson, D.: The cost of being dormant in the tropics, Biotropica, 6, 260-262, 1974.

Justice, C., Vermote, E., Townshend, J., Defries, R., Roy, D., Hall, D., Salomonson, V., Privette, J., Riggs, G., Strahler, A., Lucht, W., Myneni, R., Knyazikhin, Y., Running, S., Nemani, R., Wan, Z., Huete, A., van Leeuwen, W., Wolfe, R., Giglio, L., Muller, J., Lewis, P., and Barnsley, M.: The Moderate Resolution Imaging Spectroradiometer (MODIS): land remote sensing for global change research, IEEE T. Geosci. Remote, 36, 12281249, doi:10.1109/36.701075, 1998.

Kozlowski, T.: Carbohydrate sources and sinks in woody-plants, Bot. Rev., 58, 107-222, doi:10.1007/BF02858600, 1992.

Krepkowski, J., Bräuning, A., Gebrekirstos, A., and Strobl, S.: Cambial growth dynamics and climatic control of different tree life forms in tropical mountain forest in Ethiopia, Trees, 25, 5970, doi:10.1007/s00468-010-0460-7, 2011.

Lewis, S. L., Malhi, Y., and Phillips, O. L.: Fingerprinting the impacts of global change on tropical forests, Philos. T. R. Soc. B, 359, 437-462, 2004.

Lisi, C. S., Tomazello, M., Botoss, P. C., Roig, F. A., Maria, V. R. B., Ferreira-Fedele, L., and Voigt, A. R. A.: Tree-ring formation, radial increment periodicity, and phenology of tree species from a seasonal semi-deciduous forest in southeast Brazil, Iawa J., 29, 189-207, 2008.

Lloyd, J. and Farquhar, G. D.: Effects of rising temperatures and $\mathrm{CO}_{2}$ on the physiology of tropical forest trees, Philos. T. R. Soc. B, 363, 1811-1817, 2008.

Lola da Costa, A. C., Galbraith, D., Almeida, S., Tanaka Portela, B. T., da Costa, M., de Athaydes Silva Junior, J., Braga, A. P., de Goncalves, P. H. L., de Oliveira, A. A. R., Fisher, R., Phillips, O. L., Metcalfe, D. B., Levy, P., and Meir, P.: Effect of $7 \mathrm{yr}$ of experimental drought on vegetation dynamics and biomass storage of an eastern Amazonian rainforest, New Phytol., 187, 579-591, doi:10.1111/j.1469-8137.2010.03309.x, 2010.

Loubry, D.: Phenology of deciduous trees in a French-Guianan forest (5 degrees latitude North) - case of a determinism with endogenous and exogenous components, Can. J. Bot., 72, 18431857, 1994.

Malhi, Y. and Grace, J.: Tropical forests and atmospheric carbon dioxide, Trends Ecol. Evol., 15, 332-337, 2000.

Malhi, Y., Aragao, L. E. O. C., Galbraith, D., Huntingford, C., Fisher, R., Zelazowski, P., Sitch, S., McSweeney, C., and Meir, P.: Exploring the likelihood and mechanism of a climatechange-induced dieback of the Amazon rainforest, P. Natl. Acad. Sci. USA, 106, 20610-20615, doi:10.1073/pnas.0804619106, 2009.
Malhi, Y., Doughty, C., and Galbraith, D.: The allocation of ecosystem net primary productivity in tropical forests, Philos. T. R. Soc. B, 366, 3225-3245, doi:10.1098/rstb.2011.0062, 2011.

Meroni, M., Busetto, L., Colombo, R., Guanter, L., Moreno, J., and Verhoef, W.: Performance of spectral fitting methods for vegetation fluorescence quantification, Remote Sens. Environ., 114, 363-374, doi:10.1016/j.rse.2009.09.010, 2010.

Michelot, A., Simard, S., Rathgeber, C., Dufrene, E., and Damesin, C.: Comparing the intra-annual wood formation of three European species (Fagus sylvatica, Quercus petraea and Pinus sylvestris) as related to leaf phenology and nonstructural carbohydrate dynamics, Tree Physiol., 32, 1033-1045, doi:10.1093/treephys/tps052, 2012.

Mitchell, T. and Jones, P.: An improved method of constructing a database of monthly climate observations and associated high-resolution grids, Int. J. Climatol., 25, 693-712, doi:10.1002/joc.1181, 2005.

Molto, Q., Rossi, V., and Blanc, L.: Error propagation in biomass estimation in tropical forests, Meth. Ecol. Evolut., 4, 175-183, doi:10.1111/j.2041-210x.2012.00266.x, 2013.

Moura, Y. M., Galvao, L. S., dos Santos, J. R., Roberts, D. A., and Breunig, F. M.: Use of MISR/Terra data to study intra- and interannual EVI variations in the dry season of tropical forest, Remote Sens. Environ., 127, 260-270, doi:10.1016/j.rse.2012.09.013, 2012.

Myneni, R. B., Hall, F. G., Sellers, P. J., and Marshak, A. L.: The meaning of spectral vegetation indices, IEEE T. Geosci. Remote, 33, 481-486, 1995.

Myneni, R. B., Yang, W., Nemani, R. R., Huete, A. R., Dickinson, R. E., Knyazikhin, Y., Didan, K., Fu, R., Juarez, R. I. N., Saatchi, S. S., Hashimoto, H., Ichii, K., Shabanov, N. V., Tan, B., Ratana, P., Privette, J. L., Morisette, J. T., Vermote, E. F., Roy, D. P., Wolfe, R. E., Friedl, M. A., Running, S. W., Votava, P., El-Saleous, N., Devadiga, S., Su, Y., and Salomonson, V. V.: Large seasonal swings in leaf area of Amazon rainforests, P. Natl. Acad. Sci. USA, 104, 4820-4823, doi:10.1073/pnas.0611338104, 2007.

Nath, C. D., Dattaraja, H. S., Suresh, H. S., Joshi, N. V., and Sukumar, R.: Patterns of tree growth in relation to environmental variability in the tropical dry deciduous forest at Mudumalai, southern India, J. Biosciences, 31, 651-669, 2006.

Nemani, R., Keeling, C., Hashimoto, H., Jolly, W., Piper, S., Tucker, C., Myneni, R., and Running, S.: Climate-driven increases in global terrestrial net primary production from 1982 to 1999, Science, 300, 1560-1563, doi:10.1126/science.1082750, 2003.

Nepstad, D., Moutinho, P., Dias, M., Davidson, E., Cardinot, G., Markewitz, D., Figueiredo, R., Vianna, N., Chambers, J., Ray, D., Guerreiros, J., Lefebvre, P., Sternberg, L., Moreira, M., Barros, L., Ishida, F., Tohlver, I., Belk, E., Kalif, K., and Schwalbe, K.: The effects of partial throughfall exclusion on canopy processes, aboveground production, and biogeochemistry of an Amazon forest, J. Geophys. Res.-Atmos., 107, 8085, doi:10.1029/2001JD000360, 2002.

O'Brien, J. J., Oberbauer, S. F., Clark, D. B., and Clark, D. A.: Phenology and stem diameter increment seasonality in a Costa Rican wet tropical forest, Biotropica, 40, 151-159, 2008.

Pan, Y., Birdsey, R. A., Fang, J., Houghton, R., Kauppi, P. E., Kurz, W. A., Phillips, O. L., Shvidenko, A., Lewis, S. L., 
Canadell, J. G., Ciais, P., Jackson, R. B., Pacala, S. W., McGuire, A. D., Piao, S., Rautiainen, A., Sitch, S., and Hayes, D.: A large and persistent carbon sink in the world's forests, Science, 333, 988-993, doi:10.1126/science.1201609, 2011.

Pennec, A., Gond, V., and Sabatier, D.: Tropical forest phenology in French Guiana from MODIS time series, Remote Sens. Lett., 2, 337-345, 2011.

Phillips, O. L., Aragao, L. E. O. C., Lewis, S. L., Fisher, J. B., Lloyd, J., Lopez-Gonzalez, G., Malhi, Y., Monteagudo, A., Peacock, J., Quesada, C. A., van der Heijden, G., Almeida, S., Amaral, I., Arroyo, L., Aymard, G., Baker, T. R., Banki, O., Blanc, L., Bonal, D., Brando, P., Chave, J., Alves de Oliveira, A. C., Cardozo, N. D., Czimczik, C. I., Feldpausch, T. R., Freitas, M. A., Gloor, E., Higuchi, N., Jimenez, E., Lloyd, G., Meir, P., Mendoza, C., Morel, A., Neill, D. A., Nepstad, D., Patino, S., Cristina Penuela, M., Prieto, A., Ramirez, F., Schwarz, M., Silva, J., Silveira, M., Thomas, A. S., ter Steege, H., Stropp, J., Vasquez, R., Zelazowski, P., Alvarez Davila, E., Andelman, S., Andrade, A., Chao, K.-J., Erwin, T., Di Fiore, A., Honorio, C., E., Keeling, H., Killeen, T. J., Laurance, W. F., Pena Cruz, A., Pitman, N. C. A., Nunez Vargas, P., Ramirez-Angulo, H., Rudas, A., Salamao, R., Silva, N., Terborgh, J., and Torres-Lezama, A.: Drought sensitivity of the Amazon rainforest, Science, 323, 1344-1347, doi:10.1126/science.1164033, 2009.

Poorter, L. and Kitajima, K.: Carbohydrate storage and light requirements of tropical moist and dry forest tree species, Ecology, 88, 1000-1011, doi:10.1890/06-0984, 2007.

Rice, A. H., Pyle, E. H., Saleska, S. R., Hutyra, L., Palace, M., Keller, M., de Camargo, P. B., Portilho, K., Marques, D. F. and Wofsy, S. C.: Carbon balance and vegetation dynamics in an oldgrowth Amazonian forest, Ecol. Appl., 14, S55-S71, 2004.

Richardson, A. D., Carbone, M. S., Keenan, T. F., Czimczik, C. I., Hollinger, D. Y., Murakami, P., Schaberg, P. G., and Xu, X.: Seasonal dynamics and age of stemwood nonstructural carbohydrates in temperate forest trees, New Phytol., 197, 850-861, doi:10.1111/nph.12042, 2013.

Rocha, A. V.: Tracking carbon within the trees, New Phytol., 197, 685-686, doi:10.1111/nph.12095, 2013.

Rutishauser, E., Wagner, F., Herault, B., Nicolini, E.-A., and Blanc, L.: Contrasting above-ground biomass balance in a neotropical rain forest, J. Veg. Sci., 21, 672-682, doi:10.1111/j.1654-1103.2010.01175.x, 2010.

Rowland, L., Hill, T. C., Stahl, C., Siebicke, L., Burban, B., Zaragoza-Castells, J., Ponton, S., Bonal, D., Meir, P., and Williams, M.: Evidence for strong seasonality in the carbon storage and carbon use efficiency of an Amazonian forest, Glob. Change Biol., doi:10.1111/gcb.12375, 2013.

Sabatier, D. and Puig, H.: Phénologie et saisonnalité de la floraison et de la fructification en forêt dense guyanaise, Memoir. Mus. Natl. Hist. A-Zool., 132, 173-184, 1986.

Sabatier, D., Grimaldi, M., Prevost, M., Guillaume, J., Godron, M., Dosso, M., and Curmi, P.: The influence of soil cover organization on the floristic and structural heterogeneity of a Guianan rain forest, Plant Ecol., 131, 81-108, 1997.

Saleska, S. R., Miller, S. D., Matross, D. M., Goulden, M. L., Wofsy, S. C., da Rocha, H. R., de Camargo, P. B., Crill, P., Daube, B. C., de Freitas, H. C., Hutyra, L., Keller, M., Kirchhoff, V., Menton, M., Munger, J. W., Pyle, E. H., Rice, A. H., and Silva, H.: Carbon in Amazon forests: unexpected seasonal fluxes and disturbance-induced losses, Science, 302, 1554-1557, 2003.

Saleska, S. R., Didan, K., Huete, A. R., and da Rocha, H. R.: Amazon forests green-up during 2005 drought, Science, 318, 612, doi:10.1126/science.1146663, 2007.

Samanta, A., Ganguly, S., Hashimoto, H., Devadiga, S., Vermote, E., Knyazikhin, Y., Nemani, R. R., and Myneni, R. B.: Amazon forests did not green-up during the 2005 drought, Geophys. Res. Lett., 37, L05401, doi:10.1029/2009GL042154, 2010.

Schongart, J., Piedade, M., Ludwigshausen, S., Horna, V., and Worbes, M.: Phenology and stem-growth periodicity of tree species in Amazonian floodplain forests, J. Trop. Ecol., 18, 581597, doi:10.1017/S0266467402002389, 2002.

Solano, R., Didan, K., Jacobson, A., and Huete, A. (Eds.): Terrestrial Biophysics and Remote Sensing Lab - The University of Arizona, MODIS Vegetation Indices (MOD13) C5 User's Guide, Version 1.00, 2010.

Solomon, S., Qin, D., Manning, M., Marquis, M., Averyt, K., Tignor, M. M., H. LeRoy Miller, J., and Chen, Z. (Eds.): Climate Change 2007, the Fourth Assessment Report (AR4), Intergovernmental Panel on Climate Change, 2007.

Solomon, S., Plattner, G.-K., Knutti, R., and Friedlingstein, P.: Irreversible climate change due to carbon dioxide emissions, P. Natl. Acad. Sci. USA, 106, 1704-1709, doi:10.1073/pnas.0812721106, 2009.

Stahl, C., Burban, B., Bompy, F., Jolin, Z. B., Sermage, J., and Bonal, D.: Seasonal variation in atmospheric relative humidity contributes to explaining seasonal variation in trunk circumference of tropical rain-forest trees in French Guiana, J. Trop. Ecol., 26, 393-405, doi:10.1017/S0266467410000155, 2010.

Stahl, C., Burban, B., Wagner, F., Goret, J.-Y., Bompy, F., and Bonal, D.: Influence of seasonal variations in soil water availability on gas exchange of tropical canopy trees, Biotropica, 45, 155-164, 2013.

Tian, H. Q., Melillo, J. M., Kicklighter, D. W., McGuire, A. D., Helfrich, J. V. K., Moore, B., and Vorosmarty, C. J.: Effect of interannual climate variability on carbon storage in Amazonian ecosystems, Nature, 396, 664-667, 1998.

Verbeeck, H., Peylin, P., Bacour, C., Bonal, D., Steppe, K., and Ciais, P.: Seasonal patterns of $\mathrm{CO}_{2}$ fluxes in Amazon forests: fusion of eddy covariance data and the ORCHIDEE model, J. Geophys. Res.-Biogeo., 116, G02018, doi:10.1029/2010JG001544, 2011.

Wagner, F., Hérault, B., Stahl, C., Bonal, D., and Rossi, V.: Modeling water availability for trees in tropical forests, Agr. Forest Meteorol., 1202-1213, doi:10.1016/j.agrformet.2011.04.012, 2010a.

Wagner, F., Rutishauser, E., Blanc, L., and Herault, B.: Effects of plot size and census interval on descriptors of forest structure and dynamics, Biotropica, 42, 664-671, 2010b.

Wagner, F., Rossi, V., Stahl, C., Bonal, D., and Herault, B.: Water availability is the main climate driver of neotropical tree growth, Plos One, 7, e34074, doi:10.1371/journal.pone.0034074, 2012.

Worbes, M.: Annual growth rings, rainfall-dependent growth and long-term growth patterns of tropical trees from the Caparo Forest Reserve in Venezuela, J. Ecol., 87, 391-403, 1999.

Wright, S. and Vanschaik, C.: Light and the phenology of tropical trees, Am. Nat., 143, 192-199, doi:10.1086/285600, 1994. 
Wurth, M., Pelaez-Riedl, S., Wright, S., and Korner, C.: Nonstructural carbohydrate pools in a tropical forest, Oecologia, 143, 11-24, doi:10.1007/s00442-004-1773-2, 2005.

Zalamea, M. and Gonzalez, G.: Leaffall phenology in a subtropical wet forest in Puerto Rico: from species to community patterns, Biotropica, 40, 295-304, doi:10.1111/j.17447429.2007.00389.x, 2008.
Zhang, X., Friedl, M. A., Schaaf, C. B., Strahler, A. H., Hodges, J. C. F., Gao, F., Reed, B. C., and Huete, A.: Monitoring vegetation phenology using MODIS, Remote Sens. Environ., 84, 471-475, 2003. 